\title{
MELIBEA'S MOTHER AND CELESTINA
}

\author{
Michael Harney \\ University of Texas at Austin
}

In Act IV of Celestina the title character is admitted into Melibea's house. Alisa, Melibea's mother, is reminded by the servant girl Lucrecia that this is that same old woman who had once been pilloried "por hechizera," who "vendía las moças a los abades y descasava mil casados." Apparently ignoring this seemingly sinister intelligence, Alisa inquires as to the old woman's "officio." Lucrecia, after mentioning perfumer "y otros treynta officios," declares her best known as an herbalist, a healer of infants, a lapidary. When Lucrecia, after some hesitation, pronounces Celestina's name, Alisa, laughingly recalling the old woman as "una buena pieça," orders Lucrecia to admit her. Addressing Celestina as "vezina honrrada," Alisa declares that her guest's "razón y offrecimiento" inspire such sympathy that she would rather aid the old lady in some way than buy the thread offered for sale-although she would, at the same time, be glad to pay handsomely for the Celestina's wares. A moment later, Alisa tells her daughter to remain with this "mujer honrrada," while she, Alisa, pays an urgent visit to her ailing sister. To this Celestina observes, in an aside: "Por aquí anda el diablo aparejando oportunidad, 
arreziando el mal a la otra." Alisa, as she takes her leave, entreats Celestina to pray for the afflicted sister. ${ }^{1}$

Why does Melibea's mother feel obligated to let Celestina into her home and, once there, why is the crone treated with such deference? Hispanomedievalists have tended to assume that Alisa's response indicates either stupidity or susceptibility to Celestina's supernatural influence. Stephen Gilman has suggested the former interpretation, while Peter Russell proposes the latter. ${ }^{2}$ Alisa, in this view, seems guilty of negligence if not of downright complicity. Without trying to diminish the importance of the supernatural or diabolic element, and without suggesting any preemptive explanation for Alisa's motives, I submit that a clue to her behavior may be sought in the feminine subculture - or counterculture - of traditional patrilineal societies. Medieval European kinship, as has been demonstrated by much recent social historiography, had, by the end of the fifteenth century, been characterized for several centuries by a thoroughly agnatic (i.e., patrilineal) ideology. The essential elements of this system were primogeniture, involving exclusion of all but the eldest male from direct inheritance and control of the patrimonial estate, and strict control of the sexuality and marriage of daughters. The typical pattern was one of disinheritance of younger sons; a marrying off of daughters, through politically advantageous matchmaking with dowry paid as a lump-sum payment to daughters and their new household; or, in the case of brotherless daughters (the apparent situation of Melibea), the recruitment of sons-in-law as surrogate male heirs of their brides' lineage (i.e., as providers of inheriting grandchildren for that lineage), in the pattern known as the epiclerate. ${ }^{3}$ The epiclerate and similar filiacentric solutions were of

' La Celestina, ed. Dorothy S. Severin (Madrid: Cátedra, 1988), 152-154. This is the ed. cited throughout the present essay.

${ }^{2}$ Gilman, The Spain of Fernando Rojas: the Intellectual and Social Landscape of "La Celestina" (Princeton: Princeton Univ. Press, 1972), 251; Russell, Temas de "La Celestina" y otros estudios del "Cid" al "Quijote» (Barcelona: Ariel, 1978), 263; both cited in Severin's ed., $n$ 13, pp. 153-154.

${ }^{3}$ The implications of agnatic policy are summarized by David Herlihy, Medieval Households (Cambridge: Harvard University Press, 1985), 82-3. The principal work of defining medieval agnatic ideology and practice has been done by Georges Duby, in a number of articles and books too numerous of citation here. See relevant index headings and bibliographic references in Herlihy. For 
special importance in Peninsular tradition, given that, as Julian PittRivers observes, the woman retains not only her maiden name, bequeathed to her children as their second surname, but also any titles that may be transmitted through her, "in default of a male heir in the same degree of kinship." A brotherless daughter, then, may bear a title hereditary in her patrilineage; her husband "takes it by courtesy, as her consort." In this sense, Pitt-Rivers affirms, the women "take on a social attribute of men, becoming substitutes for them." The general import of such practices, whether with regard to titles or property or both, is that "a Spanish woman of high birth is able to transmit her patrilineal status to her children."

Agnation and the epiclerate-albeit in somewhat modified form-are clearly implied in the Celestina, although these concerns are not at the forefront of the drama. With regard to property and status, we have Calisto's allusion to Melibea's "nobleza," the "antigüedad de su linaje," and her "grandíssimo patrimonio" (I, p. 100). Much later Pleberio imparts to his wife some of the essential elements of the epiclerate, including the dilemma of the family without male heirs and the need to recruit an appropriate son-in-law:

Demos nuestra hazienda a dulce successor; acompañemos nuestra única hija con marido, cual nuestro estado requiere. . . Lo qual con mucha diligencia devemos poner desde agora por obra. . . [y] No quede por nuestra negligencia nuestra hija en manos de tutores, pues pareçerá ya mejor en su propia casa que en la nuestra (XVI, p. 302).

The factor that does not correspond to the epiclerate as typically practiced is the implied post-marital residence of Melibea, in the

broad literary and cultural implications, see R. Howard Bloch, Etymologies and Genealogies. A Literary Anthropology of the French Middle Ages (Chicago: University of Chicago Press, 1983), 92-127. For the epiclerate and its implications, see Jack Goody, "Strategies of Heirship," Comparative Studies in Society and History 15 (1973): 3-20 (10-13), and his Development of the Family and Marriage in Europe (Cambridge: Cambridge Univ. Press, 1983), 43, 53, 259, 261.

"Pitt-Rivers, "Honour and Social Status," in Honour and Shame. The Values of Mediterranean Society, ed. J. G. Peristiany (Chicago: University of Chicago Press, 1966. Rpt., 1974), 21-77 (68-69). 
match envisioned by Pleberio. Where the epiclerate customarily involves a son-in-law taking up residence with his bride's kin (what Jack Goody calls a "filiacentric union"), the Celestina conveys a notion of neolocal (involving an independent household for the married couple) or perhaps patrilocal residence (i.e., with husband's kin). The latter possibility may be preferred in the society for which the work was written, even in cases of heiresses who, like Melibea, are only children. Pleberio, in his lament, speaks to his wife of their daughter: "vez allí a la que tú pariste y yo engendré, hecha pedacos" (XXI, p. 336). This notion of the paternal procreative function and its maternal, merely uterine correlative is a central tenet of agnatic ideology. The Poema de Mio Cid makes the Cid's daughter's express the identical sentiment to their father: "Vós nos engendrastes, nuestra madre nos parió' (2595). ${ }^{5}$ One need not invoke Aristotle's concepts of masculine form and feminine matter to account for this agnatic commonplace. At the same time, there is likewise no need to minimize the classical learning that underlies the work's conscious philosophical outlook (one of its most copiously documented aspects). Let us say, rather, that the same Hellenic culture which gave us Aristotle, with his notions of sexuality, inheritance, and lineage, also gave us the very term epiclerate. We might even say, then; that what attracts Rojas and all his generation to the Aristotelian view of procreation and genealogy is the convergent social evolution that produced agnatic ideologies in both Ancient Greece and later Medieval Europe. ${ }^{6}$

What is the place of a Celestina in this patrilineal context? To answer this question we must clarify what I am tempted to call her job description. To begin with the superficial: she is a vender of household services, of medicines, of baubles. What the late John $\mathrm{K}$. Walsh said of Juan Ruiz's Trotacoventos applies as well to Celestina: her figure is surrounded with "long lists of her drugs and potions, jewels and trinkets, her devices and ruses. . . so that her definition and character. . . rise from the bizarre web she makes of people and

${ }^{5}$ Poema de mio Cid, ed. Ian Michael, 2nd ed. (Madrid: Castalia, 1984).

${ }^{6}$ Michael Gagarin (Early Greek Law, Berkeley: Univ. of California Press, 1986) glosses the term epicleros in its original context, as applying "only to a woman who in the absence of male heirs is temporarily 'attached to the estate (kleros)' until some man, normally a relative of hers, marries her and takes control of the property, which will eventually pass to their offspring" $(67, n 72)$. 
things." ${ }^{\prime 7}$ This description harmonizes with Julio Caro Baroja's characterization-based on a contrast suggested by Jacob Burckhardt- of the Mediterranean style of witch. As typified by the Italian streghe, such witches lived by fortune telling and divining, although, according to popular belief, they supplemented these activities by the purveyance of love potions. Their magical and pharmacological faculties could inflict disease and infirmity, particularly on children. The Mediterranean witch contrasts with Germanic and Nordic sorceresses-given to well-known mystic and orgiastic excesses-by her canny pragmatism, her sensible commitment to witchcraft as a trade. In it for the money, she is above all "an aider and abettor of pleasure." Regional and ethnic distinctions, suggests Caro Baroja, are therefore not the explanation for the difference. The contrast is more likely rural and urban, with Celestina the "archetype" of the Castilian or Andalusian witch so common in towns like Toledo, Salamanca and Seville in late medieval and Renaissance times.

Despite Rojas's use of classical literary models, his personage corresponds very closely to the "real thing." The typical profile revealed in the records of inquisitorial tribunals corresponds to a likeness of Celestina: a prostitute in her youth, she "becomes a procuress and go-between in her old age," as well as a fabricator of perfumes, cosmetics and beauty products. Proficient in magic, especially erotic spells and potions, she is also a skilled herbalist, a conjurer of devils, a deviser of spells and encantations, of ten requiring illicit or deviant materials (e.g., fat of the dead or of children). Her collaborators, clients, and victims are "all city-dwellers living in a pleasure-loving society." Relying on "serving maids, keepers of hosteleries, female hermits, prostitutes, young gipsies and girls of Moorish descent" as co-conspirators, these old women were supported by a clientele of "rogues and bandits at one end of the social scale and knights at the other." Celestina is, in short, "a low-

7 John K. Walsh, "The Names of the Bawd in the Libro de buen amor," in Florilegium Hispanicum: Medieval and Golden Age Studies Presented to Dorothy Clotelle Clarke, eds. John Geary, Charles Faulhaber, et. al. (Madison: Hispanic Seminary of Medieval Studies, 1983), 155. 
born daughter of an urban area, an intelligent and evil offspring of the city. ${ }^{\prime 8}$

This urban world is obsessed with reputation, with the point of honor as a matter of the ¿qué dirán? In this intimate community, characterized by Johan Huizinga as an environment of "cruel publicity," everybody knows everybody. It has been observed that honor and shame, as functions of public opinion, have an overwhelming influence on the inhabitants of "small scale, exclusive societies where face to face personal, as opposed to anonymous, relations are of paramount importance." ${ }^{\prime 9}$ What might be useful to remember is that men and women may have different notions of what constitutes reputation and social standing. This is a kin-ordered world, dominated, from the patriarchal viewpoint, by the notion of the heiress as vector of lineal identity and continuity. With regard to official agnatic marital policy, we note that all may not be taken at face value as to the efficiency or consistency of such policy in controlling the marriages of daughters. Certainly the official notion that women circulate among lineages, as commodified representatives of lineal prestige and inter-lineage alliance, is to be taken with the proverbial grain of salt.

Male patrilineal informants tell ethnographers what the text of Celestina tells us: that the source of tension in any tale of illicit love derives from the fact that agnatic policy makes the go-between and her youthful collaborators fear discovery by the lineage of the intended bride. But the vigilance of enforcers of such policy of itself implies a frequent resistance; women do not quietly submit. The "exchangist" procedure critiqued by Luce Irigaray in her analysis of circulation, exchange and commodification of women, as practiced by men in real-world patriarchal societies, and as theoretically analyzed by anthropologists like Claude Lévi-Strauss, is in fact as abstract in the field of practice as it is in the ethnographer's theoretical speculation. Irigaray observes that in ethnographic theory and in phallocentric practice, "women always pass from one man to another, from one group of men to another." Man, in this pattern, "begets man as his own likeness," while "wives, daughters, and sisters have value

${ }^{8}$ Julio Caro Baroja, The World of the Witches, trans. O. N. V. Glendinning (Chicago: University of Chicago Press; 1964), 99-102.

\footnotetext{
${ }^{9}$ Peristiany, intro. to Honour and Shame. The Values of Mediterranean Society, 11.
} 
only in that they serve as the possibility of, and potential benefit in, relations among men." In such a scheme, the "use of and traffic in women" underwrites a system whereby "men make commerce of [women], but they do not enter into any exchanges with them."10

This assessment of marital exchange and commodification accepts the official intentions of patrilineal matchmaking as actual practice. It takes at face value the agnatic contention that such policy, in furtherance of the controlling directives of patrilineal logic and its priorities, is implemented with strict efficiency and above all with the unwavering conformity of mothers and daughters. It has been suggested that critiques such as Irigaray's, in taking agnation at its word, are giving such ideology too much credit. To do so induces a disregard of the preferential aspect of marriage rules. Such rules, in this literal view, are thus taken as actual depictions of marital practice, rather than the ideals of would-be patriarchs, or idealizing models invoked for heuristic purposes (however rigid and "legalistic" these, in their theoretical austerity, may seem to be) by such persuaded strucuralists as Lévi-Strauss and Dumont. ${ }^{11}$ Laurel Bossen, for example, criticizes transactional terminology such as that employed by Irigarry. Men are indeed transactors, women are indeed transacted. But this is a preference expressed, within patrilineal systems, as if it were a description of actual practice. In point of fact, it may be "certain types of rights in women (labor, sexual, reproductive) [that] are what are being transacted, not the women themselves." Bossen argues that the transactional paradigm, in its simplicity, overlooks the fact that "women often reject, veto, or nullify the agreements made between men, making men scramble to restore economic order when women disrupt their arrangements." Two

${ }^{10}$ Luce Irigary, This Sex Which is Not One (Ithaca: Cornell University Press, 1985), 171-172, 193.

${ }^{11}$ For structuralist models of exchange, see chaps. 8, 9 and 10 of Lévi-Strauss, The Elementary Structures of Kinship, rev. ed., trans., James Harle Bell, John Richard von Sturmer, and Rodney Needham (Boston: Beacon Press, 1969), and Dumont, "Marriage Alliance," International Encyclopedia of the Social Sciences, ed. David L. Sills, 17 vols. (New York: MacMillan, 1968): 10: 19-23 (20-21). 
questions must therefore be asked: "why women permit themselves to be transacted," and "whether men are transacted." 12

Given that "official" agnatic ideology may not always get its way, we may suppose that the the zone of operation of a Celestina is the gap between the intention and the execution of patriliny. At the same time, women, if they are circulated and commodified, may well not view the proceedings of agnation with the same concern or understanding as their husbands, fathers, and brothers. To put it yet another way: there are two Alisa's, two Melibea's, two Celestina's, all of whom must be born in mind when reading the Celestina. There is an Alisa who is a typical real mother of an only daughter in late medieval patrilineal society. There is a typical Melibea, an heiress with her own idiosyncratic desires and life-preferences. And finally, there is a real Celestina who must make her way in a world officially dominated by men and men's legitimizing laws and codes, a world made vulnerable by its very rigidity to the unhampered finesse of the go-between. This Celestina's chief function is brokerage in all its forms. Her real power derives from the unintended perquisites of brokerage and mediation in a system which marginalizes sentiment and sexuality. The genuine magic of the go-between is her ability to expedite romance, in a context in which romance-a spinoff of agnatic commodification-is relegated to an emotional black market.

If Celestina's drawing card as an amorous go-between is the prurience of the illicit, it is because the patrilineal system insists on establishing a taboo around the question of marital consent. From the twelfth century, we know, the Church had inculcated the notion of individual consent as the definitive factor in matrimony. We know as well that for centuries lines were drawn within extended families between the control-obsessed patriarchal minority and the liberationist majority, with many a family and clan torn by the

${ }^{12}$ Laurel Bossen, "Toward a Theory of Marriage: The Economic Anthropology of Marriage Transactions," Ethnology 27 (1988): 127-144 (133, 142); both Irigary and Bossen cited by Flanagan, who summarizes the recent feminist polemic concerning the "androcentric bias" of Lévi-Strauss's model of the circulation and exchange of women" (251-2). 
dispute between the two factions. ${ }^{13}$ From the perspective of a patrilineal mentality ever on the defensive, "love" decodes as "willful and selfish disregard of clanic imperatives in favor of individual amorous or marital preference." It is in light of this kind of tension that we may better understand Pleberio's lament, which condemns love as the ultimate cause of disaster: "Del mundo me quexo," cries Melibea's father, "porque en sí me crió, porque no me dando vida no engendrara en él a Melibea; no nascida, no amara; no amando, cessara mi quexosa y desconsolada postremería" (XXI, p. 343).

The taboo which is at the center of the drama is that the female shall not make her own marriage; this is the privilege assumed by Pleberio in his desperate reference to the need to find Melibea a husband. When all goes according to plan in a patrilineal system employing primogeniture or epiclerate on the one hand (with the latter a female rendition of the former), and dowry and disinheritance on the other (with the former frequently a dissembled version of the latter), women with male siblings are married "up and out," and with dowry, often in the pattern known as hypergamy (woman marrying up), while younger male siblings are cut adrift, forming a de facto youth subculture, the unruly and bellicose unmarried juvenes first defined by Georges Duby. ${ }^{14}$ It was this youth which was very

${ }^{13}$ The bibliography on this topic is enormous. Duby (Medieval Marriage. Two Models from Twelfth-Century France, trans. Elborg Forster, Baltimore: Johns Hopkins Press, 1978) provides the elegant model of two marriages: one laic, involving a pactum conjugale, a "treaty. . . between two houses" (4); one ecclesiastical, emphasizing "the union of two hearts in marriage" and the "consent (consensus) of the two individuals" (17). For the social implications of this conflict between kin-ordered economic and political pragmatism and consensual individualism, see Coody, Development of the Family and Marriage, 146153. For a thorough presentation of doctrinal background, see James A. Brundage, Law, Sex, and Christian Society in Medieval Europe (Chicago: Univ. of Chicago Press, 1987), 235-42, 262-78.

${ }^{14}$ Georges Duby, "Dans la France du Nord-Ouest au XII" siècle: les 'Jeunes' dans la société aristocratique," in his Hommes et structures du Moyen Age (Paris: Mouton, 1973) 213-225; for the Spanish version of this youth culture, see Susana M. Belmartino, "Estructura de la familia y 'edades sociales' en la aristocracia de León y Castilla según las fuentes literarias e historiográficas (siglos X-XIII)," Cuadernos de Historia de España 47-48 (1968): 287-95, 301-302, 313-319. A thorough presentation of the dowry problem is that of Diane Owen Hughes, "From Brideprice to Dowry in Mediterranean Europe," Iournal of Family History 3 (1978): 262-96 (262-69, 276-85, 288-90). 
possibly the pool from which families compelled to resort to the epiclerate might recruit their sons-in-law marrying in. The configuration of variables resulting from this agnatic equation-primogeniture, disinheritance of daughters and younger sons, hypergamy with dowry, hypogamy with epiclerate-appears to have lasted for centuries, with variable consistency, but enough coherence as an array of marital contingencies and strategies to yield a variety of familiar literary models (Amadís, Oriana and the latter's younger sister; Tirant, Carmesina and the latter's elder sister; the Zifar's Roboán and his bride Seringa; Curial, Güelfa and the latter's brother). ${ }^{15}$

Pierre Bourdieu's treatment of marriage offers much which is applicable to all of Mediterranean culture, on both North and South shores. Providing the outlines of a definition of what he calls the "unofficial" female culture of the patrilineal society, he shows how the "official" agnatic culture of the clanic world presents a codified,

${ }^{15}$ For the hypogamic tendencies of the marriage market resulting from agnatic ideology and the youth subculture, see Duby, "Le mariage dans la société du haut moyen âge," in Matrimonio nella società altomedievale. Settimane di studio del Centro Italiano di Studi sull' Alto Medioevo, 2 vols. (Spoleto: Presso la Sede del Centro), 1: 15-39 (29-30); also Fernand Verkauteren, "A Kindred in Northern France in the Eleventh and Twelfth Centuries," in The Medieval Nobility, ed. Timothy Reuter (Oxford: North-Holland Publishing Co., 1978), 223-245 (228-37). Concerning parallels between Amadis and Celestina, Américo Castro ("La Celestina" como contienda literaria, Madrid: Ediciones Revista de Occidente, 1965) remarks that love for Amadís "posee dimensión social y pública," while Calisto's love "es hermético y sigiloso" (159). While chivalric love-always pointing to its eventual public revindication, which is also a vindication of the "institución caballeresca"-is only secret at first, the love of Calisto for Melibea is the "ansia impotente de un joven adinerado encendido de sensualidad" (160). Don Américo perhaps compares the two lovers unfairly: it is not chivalry, public or private, authentic or bastardized, that makes them comparable, but their marginalization, which is to say their impotence. What makes Calisto's story a tragedy is his eventual failure in death; what makes Amadis's story a romance is the eventual marriage and living happily ever after. Amadis - in its extant form, we recall, practically contemporary to Celestina-is as far removed as the latter work, in historical time, from the era when one could plausibly speak of chivalry as a social institution. The love of Amadis and Oriana is thus the fantasy fullfillment of the same desire which is ultimately repressed in Celestina. Justina Ruiz de Conde offers a more nuanced approach to amorous secrecy and its functions; see her El Amor y el matrimonio secreto en los libros de caballerías (Madrid: Aguilar, 1948), 201-13, 218-227. 
unified, dignified face to the world. The masculine domain is the world. Thus the emphasis on male networks, friendships, alliances, connections, standing in the community, in ever broader concentric rings of influence or prestige, out from the nucleus of the hearth (and always-implicitly-in potential competition with other males similarly emanating from their respective familial epicenters). The official agnatic rhetoric is always that of masculine solidarity, spontaneous teamwork, unrehearsed compliance by all clan members with the mandates of male-defined clanic policies, and in support of official (i.e., machista or phallocentric) agendas. Especially with regard to that most pivotal institution: marriage, which in the traditional world always represents a political alliance, an exchange, a linkage to broader networks for the multifarious purposes of official male culture. ${ }^{16}$

Woman's world is the hearth and household. Women are, as Bourdieu puts it, "excluded from representational kinship" (66). But their sphere, imposing its own tendencies and contradictions, is not without its own networks and agendas. Where husbands, fathers, and brothers and principal male kinsmen emphasize the pragmatic (economic, political, honorific) aspects of marital candidates, women often disregard these factors in favor of the personal happiness of their children (often especially their female children). Fathers emphasize esprit de corps: one for all. Mothers fiercely defend the specific, immediate interests of their offspring: all for one. In the cluttered reality of family life, a dialectic of role distribution insures that families argue things out, each party and its agenda against the other. The eventual marriage announcement publicly proclaimed as a unitary, self-evident statement of clanic policy is in reality the outcome of vigorous, chaotic bargaining, negotiation, rethinking, dickering, deal-making, callings-in of markers, etc. Everybody in the clan-starting with nuclear family members, but often including prestigious or otherwise influential relatives with privileged-speaker status-has his or her say, and often his or her re-say. Never mentioned publicly or officially are the candidates considered but rejected. Marriage, and all other clanic decisions, are, in other words, compromises which are hammered out rather than decrees which are

16 Pierre Bourdieu, Outline of a Theory of Practice, trans. Richard Nice, Cambridge Studies in Social Anthropology, 16 (Cambridge: Cambridge Univ. Press, 1977), 52-58, 59-64. 
foreordained (in which guise-in accordance with the needs of official male dignity - they are frequently divulged to society at large).

Despite the image of unanimity projected by the official patrilineage, the traditional kin-ordered environment is pervasively dissident and negotiatory, both between and within lineages. Hence the niche that arises for brokerage in its many guises and functions. Hence the yenta, the go-between, the matchmaker as fixtures of numerous cultures whose chief common denominator is an emphasis on agnatic control over marriage and female sexuality. As Francisco Márquez-Villanueva demonstrates, medieval Spain's "preference for arranged marriages" reveals "a certain uniformity of customs" among Christians, Moors, and Jews. Old women, often disguised as trinket sellers, are a common type of matchmaker in traditional Muslim society. Pandering and proxenetism, the blackmarket shadows of the licit matrimonial commerce represented by matchmaking, are likewise pervasive in the Orient. The clandestinity imposed by patriarchal control, with its reclusion of women, insures that the go-between "must basically be able to penetrate the privacy of women's quarters to inspect the 'market' and try to persuade the innocent during unsupervised conversation." Thus arises, according to MárquezVillanueva, the matchmaker as "a female engaged in an apparently harmless activity, like the selling of trinkets or cosmetics, or as a doctor for feminine ailments." ${ }^{17}$ Samuel Armistead and James Monroe have documented numerous striking parallels between the personages, themes, and incidents of La Celestina and a number of texts from the Muslim world, including several tales from various recensions of the Thousand and One Nights. While the Spanish work might well have incorporated elements from such Oriental texts, analogies between the Celestina and her "Muslim sisters" arise from "the common cultural background of a Mediterranean honor and shame society, in which women were carefully quarantined from contact with the opposite sex and the rôle of the go-between consequently acquired crucial significance." The relationship of the Celestina to her Muslim analogues is to understood, in other words,

\footnotetext{
${ }^{17}$ Márquez-Villanueva, "La Celestina as Hispano-Semitic Anthropology," Revue de Littérature Comparée 61 (1987): 425-56 (427, 429-30).
} 
"as generic rather than genetic," and as the natural thematic outcome of "Mediterranean literature about procuring." ${ }^{18}$

The unofficial female culture, less constrained than official patriarchy by custom, tradition, or public opinion, has the most leeway for improvisation, for establishment of negotiatory channels while maintaining escape valves that allow for, among other things, scrutiny of an exanded range of marital candidates, allowance for personal sentimental preferences, establishment of tentative or temporary relations between families, and avoidance, as Bourdieu phrases it, of "the humiliating rebuff." Hence, possibly, the reason why brokers might tend to be women unencumbered by familial restrictions-thus the crone, the spinster, the widow as go-between and matchmaker. Other functions-gossip monger, fortune teller, spellmaker, witch, sorceress, peddler, hawker, money-lender, etc.-naturally accrete to the nebulous job description of mediator. Proxenetism would be among these naturally auxiliary functions. Although Márquez-Villanueva rightly emphasizes the opposite nature of matchmaking and procuring-the former operates openly and "to the benefit of both genders," while the latter works "outside or against the 'system' and "represents a threat to the institution of arranged marriage" - the contrary nature of the functions by no means precludes their simultaneous performance by a single person. ${ }^{19}$ Hence the power of the matchmaker/procuress/witch in the unofficial, female, hearth-centered world.

To alienate the matchmaker is to risk not only the opprobrium of the lady herself-with all that this implies in the way of natural and supernatural disfavor (e.g., failure to secure appropriate matches for one's children, injurious rumors of all sorts, infertility, impotence, bad luck, and necromantical tribulations for ones's self, kith, and kin)-but also to provoke the contumely of one's fellow goodwives. The matchmaker, in other words, is the boss-lady of female society, on whose bad side one does not get. Hence the spontaneous hospitality that would be shown by a real Melibea's real mother toward a real Celestina. Speculations as to female motives which limit themselves to the supernatural menace of Celestina, or to the

${ }^{18}$ Armistead and Monroe, "Celestina's Muslim Sisters," Celestinesca 13,2 (1989): 3-27 (12-13).

${ }^{19}$ Márquez-Villanueva, 430. 
assumed naiveté or outright stupidity of Melibea's mother (and the girl herself, for that matter) impede understanding that Celestina's undoubted magical potential, her skill at voodoo stupefication and manipulation, are, in a sense, the result of her special communal standing, not the cause of it. A real-life Alisa, therefore, would show good diplomatic sense in offering consideration and trust toward a real Celestina, while a real-life Melibea might well be all too eager to resort to such a go-between precisely because of the latter's power to subvert the agnatic regime that dooms such a daughter to spinsterhood or unwanted marriage.

The probable realism of this depiction does not necessarily indicate the author's understanding or approval of the cultural circumstance he portrays. Seeing the real Celestina behind the work named for her is like trying to understand the real Hannibal or the real Spartacus by means of those unsympathetic accounts of them written by Roman historians who are our only available sources: significant details emerge from the biased narrative, but they are an inadvertent lapse, the stuff of a psycho-historical reading between the lines. Similarly, the author of La Celestina presents not real women but their gullible or self-serving or corrupt effigies; any realism we may discern or deduce is accidental, a detail that manages to get through the static of agnatic propaganda. The characters as portrayed are alternate renditions of real-life female personages, embodying, by their acting-out of the story as thematic scenario, a defense of patriarchal prerogatives and all that these imply in the way of commodification of the female. Women are shown, in other words, to be destructive of a mythical patrilineal concord whose defenders could effectively quell: familial dissension and clanic deterioration-thus threats to male honor-only in the wish-fulfilling fantasy of literary representation. 